\title{
Use of scientific research by South African winemakers
}

\section{Nelius Boshoff}

\begin{abstract}
The study investigated the extent to which transmission and cognition, the first two stages in the research use process, are accomplished for winemakers. "Transmission-cognition" was operationalized as the frequency of engagement with information sources considered to be carriers of scientific research. The study also investigated the prominence of four types of research use among winemakers (conceptual, symbolic, instrumental and persuasive) together with their interrelationship. Conceptual use of scientific information was reported by $90 \%$ of winemakers and is a precursor to the other types of research use. Findings are discussed with reference to knowledge creep and the dissemination of scientific research through central winemakers acting as nodes in social networks.
\end{abstract}

KEYWORDS: knowledge, research, use, winemaker

\section{Context}

The use of information that is based on scientific research plays an important role in the development and international competitiveness of a country's wine industry. Everchanging and more refined consumer preferences are creating a demand for multi-faceted innovation, of which scientific research is one facet, together with product development, logistics and marketing strategies. Scientific research can provide, for instance, the knowledge necessary to clarify the processes and factors that affect wine quality, and lead to the implementation of practices that can eliminate wine faults [1]. The purpose of this paper is to explore different insights into the use of scientific research by South African winemakers.

A distinction is made between research use as a process and research use as a typology. The first refers to different stages of use whereas the second highlights different types of use. As far as research use as a process is concerned, some insights can be gained from Rich's depiction of use, comprising three events [2]. The first is information pick-up, referring to the process of retrieving and receiving information. Various possibilities for retrieval and reception exist, for example, information may be accessed from an electronic databank, read in a book, transmitted through a consultant, or through a telephonic conversation with a colleague. The second event, information processing, consists of different sub-events, namely understanding the information, using cognitive procedures to assess the value of the information and testing it against one's own assumptions and beliefs, 
and transforming the information into a form that better suits the needs of the user. The last event is application, which involves deciding whether to implement the information or not.

Insights concerning research use as a process can also be gained from Knott and Wildavsky, who addressed the question as to when it can be established that use actually occurred [3]. They highlighted seven standards of use, each determining a different "cutoff" for evidence of use. Accordingly, use is said to have occurred when the research findings have physically reached the potential user (reception standard); when the potential user has read, understood and "digested" the research findings (cognition standard); when the research findings have changed the frame of reference - i.e. preference, attitude, understanding - of the potential user (reference standard); when the potential user makes an effort to adopt the research findings even if blocked by other forces (effort standard); when the research findings are formally adopted, such as appearing in a policy or practice protocol (adoption standard); when the policy or practice protocol is formally implemented (implementation criterion); and when tangible benefits are produced based on implementation (impact standard). Landry, Amara and Lamari [4] slightly modified Knott and Wildavsky's conception by merging the adoption and implementation stages into a single stage called application. Their own conception therefore consists of six cumulative stages of research use, namely transmission, cognition, reference, effort, influence and application.

As far as research use as a typology is concerned, Weiss discusses six models by which research findings can enter user domains [5]. Three of these models (problem-solving, political and enlightenment) speak directly to the issue of research use. Although Weiss developed the models with policymakers in mind, they can easily be adapted to apply to research use by practitioners as well.

The problem-solving model, where policymakers commission research or seek out existing research in response to a policy issue, provides the best example of the instrumental use of research. Since the findings are of immediate relevance to the policymakers, they find direct application in decision-making and policy interventions.

The political model of research use refers to instances where research findings are used by policymakers to strengthen existing standpoints and beliefs. This is an example of the symbolic use of research. The policymakers are not really influenced by the research findings but use the latter as ammunition to back established viewpoints.

In the enlightenment model of research use, policymakers often cannot identify a specific piece of research that has shaped their decisions, although they are very much attuned to research and have a clear sense that research has provided them with an underlying set of ideas on which they base decisions and actions. The enlightenment model is characterized by knowledge creep, or a "diffuse, undirected seepage of social research into the policy sphere" (p. 23) [6]. This is an illustration of the conceptual use of research.

A different but closely related typology is that by Estabrooks [7] who, in nursing practice, distinguishes between three types of research use: direct, indirect and persuasive. Direct use, like instrumental use, occurs where research is used to make specific deci- 
Table 1. Relationship between Stages and Types of Research Use.

\begin{tabular}{|c|c|c|c|c|}
\hline \multirow{2}{*}{ Stages of research use } & \multicolumn{4}{|c|}{ Types of research use } \\
\hline & Conceptual & Symbolic & Instrumental & Persuasive \\
\hline $\begin{array}{l}\text { 1. Transmission: I transmitted my } \\
\text { research results to the practitioners } \\
\text { and professionals concerned }\end{array}$ & -- & -- & -- & -- \\
\hline $\begin{array}{l}\text { 2. Cognition: My research reports } \\
\text { were read and understood by the } \\
\text { practitioners and professionals } \\
\text { concerned }\end{array}$ & $\sqrt{ }$ & -- & -- & -- \\
\hline $\begin{array}{l}\text { 3. Reference: My work has been } \\
\text { cited as a reference in the reports, } \\
\text { studies, and strategies of action } \\
\text { elaborated by practitioners and } \\
\text { professionals }\end{array}$ & $\mathrm{V}$ & $\sqrt{ }$ & -- & -- \\
\hline $\begin{array}{l}\text { 4. Effort: Efforts were made to } \\
\text { adopt the results of my research by } \\
\text { practitioners and professionals }\end{array}$ & $\mathrm{V}$ & V & $\mathrm{V}$ & -- \\
\hline $\begin{array}{l}\text { 5. Influence: My research results } \\
\text { influenced the choice and decision } \\
\text { of practitioners and professionals }\end{array}$ & $\mathrm{V}$ & $\mathrm{V}$ & v & $(v)$ \\
\hline $\begin{array}{l}\text { 6. Application: My research results } \\
\text { gave rise to applications and } \\
\text { extension by the practitioners and } \\
\text { professionals concerned }\end{array}$ & $\sqrt{ }$ & V & $\sqrt{ }$ & $\sqrt{ }$ \\
\hline
\end{tabular}

Compiled from: Estabrooks; Landry, Amara \& Lamari; Weiss [4-8].

sions or to implement changes in one's practice. Indirect use, in Estabrooks' study, refers to the use of research findings to shape one's thinking and alter opinions, which is not that far removed from the notion of conceptual use. Persuasive use, on the other hand, refers to the use of research findings to persuade others to make changes to current conditions, policies and practices. Estabrooks also explored the conceptual structure of research use through an advanced multivariate data analysis technique, known as structural equation modelling. Her analysis revealed a good fit between the threefold model (consisting of direct, indirect and persuasive use) and the empirical data collected for 600 nurses.

In summary, if one combines the typologies of Estabrooks [7] and Weiss [5], four types of research use can be distinguished: instrumental, conceptual, symbolic and persuasive.

One could rightfully ask how the portrayal of research use as a series of events in a process relates to the portrayal of research use as ideal types. Table 1 is an attempt to integrate the six cumulative stages of research use by Landry, Amara and Lamari with the four types of use derived from the work by Weiss and Estabrooks [4-8]. The stages of research use in Table 1 are mainly seen from the perspective of the researcher, whereas the research use types can be viewed from the perspective of either the researcher or user.

Transmission, the first stage in the research use process, is not related to any of the use types because it only implies reception of the research results. The potential user's engagement with the research transmitted only starts during the cognition stage. During 
the latter stage, when the recipient of the research findings also engages with it, conceptual use becomes applicable as insights and ideas may then start to formulate in the head of the recipient. The steps are hierarchical, implying that conceptual use, or the possibility thereof, also characterizes each of the remaining higher-order stages. Only when a user starts to refer to the results, during stage 3, does symbolic use become a reality because now the research can be used to strengthen existing standpoints. Instrumental use, or the direct application of the research results, starts to take shape during stage 4, when efforts are made to adopt the results in one's own setting. A stronger version of instrumental use characterizes stage 5 (influence), when the research results adopted directly influence one's actions or decisions. It is during this stage that those who adopted the findings can also convince others to do the same, resulting in persuasive use. During the last stage (application), all four use types can co-exist simultaneously. Table 1 also suggests that conceptual use occurs prior to any of the other types of research use.

\section{Objectives}

In the light of the above discussion the present study has five objectives in mind. The first is to establish to what degree transmission and cognition, the first two stages in the research use process, are accomplished in the case of winemakers. These two stages are important in the broader process of research use as they prepare the way for the eventual accomplishment of the higher (and politically more valued) stages of adoption and impact, collectively referred to as "application" by Landry, Amara and Lamari [4]. In the current study the first two stages are seen as a single construct, called "transmissioncognition". The latter is operationalized as the frequency of engagement with a number of information sources considered to be carriers of scientific research. Should winemakers more frequently engage with information sources not typically associated with scientific research, the second objective would be to investigate to what extent research findings also underlie those information sources. Closely related is a third objective, namely to explore winemakers' processing of the information - specifically information obtained from a frequently consulted source — in order to shed light on the information processing stage of Rich's [2] conception of research use as a process.

The fourth and fifth objectives, respectively, are to determine to what extent the four types of research use apply to winemakers as a category of practitioners, and to test the insight generated by Table 1 that conceptual use happens prior to any of the other three types of use.

\section{Methods}

According to the 2010/11 South African Wine Industry Directory [9] there were 896 winemakers in the country at that time, representing 737 wine cellars. A letter explaining the objective of the study was emailed to the wine cellars, with the request that it be forwarded to all winemakers and assistant winemakers in the organisation. Eventually 
590 emails reached their target. This figure appears realistic in the light of additional information, according to which there were 573 active wine cellars in South Africa in $2010[10]$.

The email included a hyperlink to access a web questionnaire. The winemakers had to rate 28 information sources that are pertinent to the wine industry in terms of how frequently they engage with those sources. In all cases a 4-point rating scale was used although the descriptions for the scale categories differed depending on the type of information source. Four sets of scale categories were used, with the following set being the most prevalent: at least once a month, at least once in 3 months, at least once in 6 months and never/almost never.

The winemakers also rated their agreement with four statements concerning their use of scientific research findings in winemaking (strongly agree, agree, neutral, disagree and strongly disagree). The statements were designed to measure the four types of research use, based on the typologies by Weiss and Estabrooks [5, 7]. Thus, each type of research use was measured by responses to a single question, which was the same method that Estabrooks employed in her study of nurses.

- "Scientific research findings on winemaking have led me to do things differently in my winemaking." (instrumental use)

- "Scientific research findings on winemaking have led me to develop a better understanding of some aspect of my winemaking." (conceptual use)

- "Scientific research findings on winemaking have strengthened my personal belief concerning winemaking." (symbolic use)

- "Scientific research findings on winemaking have led me to advise other winemakers to do things differently in their winemaking." (persuasive use).

The winemakers also had to indicate how often fellow winemakers normally approach them for information and advice (at least once a month, at least once in 3 months, at least once in 6 months and never/almost never).

Altogether 211 winemakers submitted usable questionnaires, translating into a response of $24 \%$. However, not all the respondents completed all the questions, which can explain why the numbers of respondents differ by analysis in the results section.

Moreover, participation was voluntary and winemakers could stop completing the web questionnaire at any time. Completion of the questionnaire was anonymous as neither the winemaker's name nor the name of the organisation was required. However, the last question stated that there would be a follow up on some of the interesting responses by means of interviews. Winemakers willing to talk in more depth about their winemaking were therefore invited to provide their contact details, but this was voluntary. Of those who provided contact details, six winemakers were selected for telephonic interviews on the basis of their availability, gender, cellar affiliation (estate, cooperative, producing wholesaler, etcetera) and because they strongly agreed with the statement that scientific 
research findings had led them to do things differently in their winemaking. Interviews were conducted to explore the winemakers' reasons for engaging with certain information sources, as well as their preferences for and use of such sources. The individual survey responses of the six winemakers were scrutinized and relevant probing questions formulated for each winemaker.

\section{Results}

The "transmission-cognition" stages of research use: winemaker engagement with sources of scientific information

To measure the transmission-cognition stage combination, the questionnaire provided the winemakers with a list of information sources (the majority of them transmitters of scientific information), which they were asked to rate in terms of how often they engage with those sources (i.e. read, consult, etcetera). The results are displayed in Table 2. Not all of the information sources are self-explanatory. For that reason clarifying descriptions, where applicable, have been included in Table 3.

Given that Table 2 reports four sets of scale categories (respectively starting with: Read everything in each edition, Once a month, At least once a month and 3 or more times), the results are best interpreted by comparing the proportions of respondents who do not engage with a particular information source. In doing so, it can be seen that winemakers tend to participate particularly in four information-sourcing activities: read Wynboer in the WineLand magazine (only $2 \%$ of winemakers never do so); seek advice from other winemakers in South Africa (only 3\% never do so); obtain feedback on the quality of wine products from wine consumers (only $7 \%$ never do so); and search the Internet for information on winemaking issues (only $8 \%$ never do so).

In addition, more than half of winemakers indicated that they never engage with certain sources, many of them sources of scientific research.

- Four such sources are written documents: Winetech Scan (64\% never read it), reports by international research organizations (63\%), international science journals $(60 \%)$, and the Winetech database of funded research $(52 \%)$.

- When seeking advice, more than half of the winemakers never consult four of the groups listed: three of these are staff members of research and training organizations, namely the Cape Institute for Agricultural Training (81\%), ARC InfruitecNietvoorbij (73\%), and Department of Viticulture and Oenology and/or the Institute for Wine Biotechnology at Stellenbosch University (59\%). The other category is winemakers outside South Africa (54\%).

- With regard to events, more than half of the winemakers never attend postgraduate student seminars at Stellenbosch University $(85 \%)$ and relevant conferences in other countries $(84 \%)$. 
Table 2. Extent to which Winemakers engage with Various Information Sources.

\begin{tabular}{|c|c|c|c|c|}
\hline $\begin{array}{l}\text { How closely do you read the following South African } \\
\text { publications? }\end{array}$ & $\begin{array}{l}\text { Read } \\
\text { everything } \\
\text { in each } \\
\text { edition }\end{array}$ & $\begin{array}{l}\text { Read parts } \\
\text { of each } \\
\text { edition }\end{array}$ & $\begin{array}{l}\text { Read only } \\
\text { some } \\
\text { editions }\end{array}$ & Do not read \\
\hline Wynboer in the WineLand magazine $(\mathrm{N}=210)$ & $19 \%$ & $55 \%$ & $24 \%$ & $2 \%$ \\
\hline Outlook Gazette by Anchor Wine Yeast $(\mathrm{N}=202)$ & $13 \%$ & $29 \%$ & $29 \%$ & $29 \%$ \\
\hline $\begin{array}{l}\text { South African Journal of Enology and Viticulture } \\
(\mathrm{N}=203)\end{array}$ & $2 \%$ & $32 \%$ & $28 \%$ & $38 \%$ \\
\hline How often do you read/consult the following sources? & $\begin{array}{l}\text { Once a } \\
\text { month }\end{array}$ & $\begin{array}{l}\text { Once in } 3 \\
\text { months }\end{array}$ & $\begin{array}{c}\text { Once in } 6 \\
\text { months }\end{array}$ & $\begin{array}{l}\text { Never / } \\
\text { almost } \\
\text { never }\end{array}$ \\
\hline Textbooks and manuals of winemaking practice $(\mathrm{N}=209)$ & $17 \%$ & $29 \%$ & $28 \%$ & $26 \%$ \\
\hline $\begin{array}{l}\text { Contributions in New World Winemaker } \\
\text { (www.newworldwinemaker.com) }(\mathrm{N}=207)\end{array}$ & $17 \%$ & $25 \%$ & $21 \%$ & $37 \%$ \\
\hline $\begin{array}{l}\text { Trade journals by the wine industries of other countries } \\
(\mathrm{N}=203)\end{array}$ & $8 \%$ & $17 \%$ & $27 \%$ & $48 \%$ \\
\hline Winetech Scan $(\mathrm{N}=203)$ & $7 \%$ & $15 \%$ & $14 \%$ & $64 \%$ \\
\hline $\begin{array}{l}\text { Findings of Winetech-funded research in the Winetech } \\
\text { database }(\mathrm{N}=203)\end{array}$ & $6 \%$ & $16 \%$ & $26 \%$ & $52 \%$ \\
\hline International science journals $(\mathrm{N}=209)$ & $4 \%$ & $14 \%$ & $22 \%$ & $60 \%$ \\
\hline Reports by international research organisations $(\mathrm{N}=210)$ & $4 \%$ & $11 \%$ & $22 \%$ & $63 \%$ \\
\hline $\begin{array}{l}\text { How often do you seek expert advice from the following } \\
\text { people? }\end{array}$ & $\begin{array}{l}\text { At least } \\
\text { once a } \\
\text { month }\end{array}$ & $\begin{array}{c}\text { At least } \\
\text { once in } 3 \\
\text { months }\end{array}$ & $\begin{array}{c}\text { At least } \\
\text { once in } 6 \\
\text { months } \\
\end{array}$ & $\begin{array}{l}\text { Never / } \\
\text { almost } \\
\text { never }\end{array}$ \\
\hline Other winemakers in South Africa $(\mathrm{N}=208)$ & $46 \%$ & $35 \%$ & $16 \%$ & $3 \%$ \\
\hline $\begin{array}{l}\text { Staff from wine laboratories responsible for wine } \\
\text { analyses }(\mathrm{N}=209)\end{array}$ & $25 \%$ & $27 \%$ & $29 \%$ & $19 \%$ \\
\hline VinPro consultants $(\mathrm{N}=209)$ & $12 \%$ & $17 \%$ & $24 \%$ & $47 \%$ \\
\hline Winemakers in other countries $(\mathrm{N}=207)$ & $8 \%$ & $13 \%$ & $25 \%$ & $54 \%$ \\
\hline $\begin{array}{l}\text { Technical consultants from other yeast manufacturing } \\
\text { companies }(\mathrm{N}=209)\end{array}$ & $2 \%$ & $14 \%$ & $51 \%$ & $33 \%$ \\
\hline $\begin{array}{l}\text { Staff from the Department of Viticulture and Oenology } \\
\text { and/or the Institute for Wine Biotechnology (IWBT) at } \\
\text { Stellenbosch University }(\mathrm{N}=209)\end{array}$ & $1 \%$ & $8 \%$ & $32 \%$ & $59 \%$ \\
\hline Technical consultants from Anchor Wine Yeast $(\mathrm{N}=210)$ & $1 \%$ & $7 \%$ & $47 \%$ & $45 \%$ \\
\hline Staff from ARC Infruitec-Nietvoorbij $(\mathrm{N}=209)$ & $1 \%$ & $4 \%$ & $22 \%$ & $73 \%$ \\
\hline $\begin{array}{l}\text { Staff from Cape Institute for Agricultural Training } \\
\text { (CIAT) }(\mathrm{N}=208)\end{array}$ & $0 \%$ & $4 \%$ & $15 \%$ & $81 \%$ \\
\hline How often do you do the following? & $\begin{array}{l}\text { At least } \\
\text { once a } \\
\text { month }\end{array}$ & $\begin{array}{c}\text { At least } \\
\text { once in } 3 \\
\text { months }\end{array}$ & $\begin{array}{c}\text { At least } \\
\text { once in } 6 \\
\text { months }\end{array}$ & $\begin{array}{c}\text { Never / } \\
\text { almost } \\
\text { never }\end{array}$ \\
\hline $\begin{array}{l}\text { Search the Internet for information on issues related to } \\
\text { winemaking }(\mathrm{N}=210)\end{array}$ & $47 \%$ & $31 \%$ & $14 \%$ & $8 \%$ \\
\hline $\begin{array}{l}\text { Obtain feedback on the quality of wine products from } \\
\text { wine consumers }(\mathrm{N}=208)\end{array}$ & $43 \%$ & $31 \%$ & $19 \%$ & $7 \%$ \\
\hline Participate in winemaker forums on the Internet $(\mathrm{N}=210)$ & $3 \%$ & $8 \%$ & $11 \%$ & $78 \%$ \\
\hline $\begin{array}{l}\text { How often have you in the past attended the following } \\
\text { events? }\end{array}$ & $\begin{array}{c}3 \text { or more } \\
\text { times }\end{array}$ & Twice & Once & $\begin{array}{c}\text { Never } \\
\text { attended }\end{array}$ \\
\hline $\begin{array}{l}\text { Information sessions/seminars/workshops by } \\
\text { Winetech/VinPro }(\mathrm{N}=210)\end{array}$ & $46 \%$ & $16 \%$ & $18 \%$ & $20 \%$ \\
\hline $\begin{array}{l}\text { Information sessions/seminars/workshops by Anchor } \\
\text { Wine Yeast }(\mathrm{N}=210)\end{array}$ & $30 \%$ & $17 \%$ & $16 \%$ & $37 \%$ \\
\hline $\begin{array}{l}\text { Workshops and short courses by the South African } \\
\text { Society for Enology and Viticulture }(\mathrm{N}=210)\end{array}$ & $29 \%$ & $18 \%$ & $17 \%$ & $36 \%$ \\
\hline $\begin{array}{l}\text { Annual conference of the South African Society for } \\
\text { Enology and Viticulture }(\mathrm{N}=208)\end{array}$ & $18 \%$ & $14 \%$ & $20 \%$ & $48 \%$ \\
\hline Relevant conferences in other countries $(\mathrm{N}=207)$ & $2 \%$ & $4 \%$ & $10 \%$ & $84 \%$ \\
\hline $\begin{array}{l}\text { Seminars at Stellenbosch University where postgraduate } \\
\text { students present their theses and dissertations }(\mathrm{N}=205)\end{array}$ & $2 \%$ & $3 \%$ & $10 \%$ & $85 \%$ \\
\hline
\end{tabular}


Table 3. Descriptions of Information Sources. Descriptions
Wynboer in the WineLand magazine - This is a monthly technical guide for South African wine producers
that appears as a section in a popular wine magazine published by VinPro, the service organisation for
wine producer members. The technical guide is sponsored by the Wine Industry Network for Expertise and
Technology (Winetech), which co-ordinates research, training and technology transfer in the wine industry.
Mostly the results of Winetech funded research are reported in Wynboer

Outlook Gazette by Anchor Wine Yeast - The latter organisation is a subdivision within Anchor Biotechnologies, a business unit of Anchor Yeast (Pty) Ltd, the leading yeast manufacturer in Africa. The Outlook Gazette is an A3-size publication published twice a year and which is distributed to winemakers. It includes practical articles on winemaking. However, at the time of this study the name of the gazette was changed to the Newworldwinemaker newsletter.

South African Journal of Enology and Viticulture - Winetech sponsors the South African Journal of Enology and Viticulture as part of its technology transfer programme. This peer-reviewed, scientific journal is published by the South African Society for Enology and Viticulture (SASEV). The journal is available as a hard copy as well as online, and scientists funded by Winetech are encouraged to publish in this journal.

Contributions in New World Winemaker - Anchor Wine Yeast shares technical news about winemaking developments in new world wine producing countries, through a dedicated website at www.newworldwinemaker.com. The latter is a non-commercial website.

Winetech Scan - This is a monthly electronic newsletter by Winetech that highlights the latest relevant international news and research results as well as the latest local Winetech funded research results and technological advancements in the wine and related agricultural sectors. The idea behind the newsletter is to stimulate research as well as to alert industry members to possible developments which could be implemented.

Findings of Winetech-funded research in the Winetech database - In conjunction with the South African Wine Industry Information and Systems (SAWIS), Winetech has compiled a research database that contains all Winetech funded research projects since 1999. Information about the projects is available at no costs on the SAWIS website and full text final reports can be requested. The database is updated every year.

VinPro consultants - These are commodity based extension agents. VinPro's viticulture consultants are present in all the wine regions and convene regularly and for that reason have an established communication structure. Their services are however directed at wine grape producers. Oenological technology transfer services, on the other hand, occur on a much smaller scale within VinPro and tend to be sub-contracted.

Technical consultants from Anchor Wine Yeast - Anchor also has a highly qualified team of technical consultants for solving specialist customer needs. These individuals can be regarded as transfer agents in the sense that they communicate knowledge about yeast and fermentation to their clientele, which consists of winemakers.

Technical consultants from other yeast manufacturing companies - These refer to the highly qualified team of technical consultants at other yeast manufacturing companies in South Africa.

Staff from the Department of Viticulture and Oenology (DVO) and/or the Institute for Wine Biotechnology (IWBT) at Stellenbosch University - The DVO is the only academic department in South Africa that offers graduate and postgraduate courses in viticulture and oenology. The department has at its disposal significant research facilities. The DVO's research projects are supported by competitive grants awarded to the department by industry (including Winetech) and government institutions. The IWBT is located in the DVO and the only research institute in the country that is focused on grapevine and wine biotechnology

Staff from ARC Infruitec-Nietvoorbij - The ARC Infruitec-Nietvoorbij is a specialist institute of the Agricultural Research Council (ARC) of South Africa and located in Stellenbosch. Its mandate is to conduct research, development and technology transfer on the breeding, cultivation and post-harvest technology of a number of crops, which include deciduous fruit and viticulture.

Staff from Cape Institute for Agricultural Training — The Cape Institute for Agricultural Training (CIAT) is located at Elsenburg outside Stellenbosch. It is a training institution of the Western Cape Provincial Department of Agriculture, offering a Diploma in Cellar Technology. CIAT also offers a BAgric programme in association with Stellenbosch University.

Information sessions/seminars/workshops by Winetech/VinPro; Information sessions/seminars/workshops by Anchor Wine Yeast; Workshops and short courses by the South African Society for Enology and Viticulture - From time to time Winetech hosts information meetings in co-operation with other bodies, e.g. VinPro and the SASEV Forum for Viticulturist and Oenology, where project findings are often presented to end-users. Feedback to end-users is important, given that Winetech is funded through a statutory industry levy and therefore accountable to its industry stakeholders.

Annual conference of the South African Society for Enology and Viticulture - Winetech sponsored research projects are also presented at SASEV conferences, which is a platform for scientific research dissemination. 
Lastly, if one approaches the results from a positive end (i.e. by establishing which sources winemakers do most frequently engage with), four information sources emerge as most prominent: read Wynboer in the WineLand magazine (74\% of winemakers do so at least once a month, i.e. $19 \%$ read everything in each monthly edition together with $55 \%$ who read parts of each edition); seek advice from fellow winemakers in the country (46\%); search the Internet for information on winemaking issues (47\%); and obtain feedback on the quality of wine products from consumers (43\%).

From the description in Table 3 it should be clear that Wynboer in the WineLand magazine includes the findings of scientific research. What remains unclear is to what extent scientific research also informs the advice obtained from fellow winemakers, the feedback by wine consumers, and material on the Internet.

Fellow winemakers, wine consumers and the Internet as information sources: any traces of scientific research?

The first topic to be tackled is what sources of information contribute to the knowledge base of South African winemakers who are singled out by other winemakers for information and advice. Table 4 summarizes the results of a series of cross-tabulations between the winemakers' information sources and the question as to how often they are approached by fellow winemakers. Table 4 lists only 17 of the original 28 information sources, as it excludes sources that more than half of winemakers indicated they never or almost never engage with. Moreover, Table 4 only reports the percentage of winemakers who frequently engage with the 17 remaining information sources. The notion of "frequently engage" assumes different meanings, depending on the nature of the information source: (1) reading every edition of a particular publication, (2) reading other kinds of publications and documents at least once in three months, (3) seeking expert advice from a certain group of individuals at least once every three months, and (4) having attended a number of information sessions at least twice in the past. The percentages are presented for four subgroups of winemakers, which correspond to the four response categories as to how often a winemaker is approached by fellow winemakers for advice.

As a rule of thumb, any information source that at least $60 \%$ of the regularly consulted winemakers $(n=70)$ said they frequently engage with, can be interpreted as contributing towards the knowledge base of that group of winemakers. Altogether eight information sources in Table 4 meet this criterion, but these can be viewed through two lenses. The first is whether the source incorporates scientific research evidence. Five of the sources are known carriers of scientific research: two of them written documents (Wynboer, 74\%; textbooks and manuals, 60\%) and three of them wine information events (Winetech/VinPro, 76\%; Anchor Wine Yeast, 64\%; SASEV, 63\%).

The second lens is whether the eight information sources sufficiently discriminate between frequently consulted $(n=70)$ and non-consulted $(n=21)$ winemakers. Four sources in particular seem to be good discriminators, namely obtaining regular feedback from wine consumers $(84 \%$ versus $43 \%$ ) and again the three sets of wine information events 
Table 4. Frequently Consulted Winemakers and Non-consulted Winemakers compared with regard to Extent of Engagement with Various Information Sources.

\begin{tabular}{|c|c|c|c|c|}
\hline \multirow[b]{2}{*}{ Information sources } & \multicolumn{4}{|c|}{$\begin{array}{l}\text { How often fellow winemakers seek } \\
\text { advice/information from respondent }\end{array}$} \\
\hline & $\begin{array}{c}\text { At least } \\
\text { once a } \\
\text { month } \\
(n=70) \#\end{array}$ & $\begin{array}{c}\text { At least } \\
\text { once in } 3 \\
\text { months } \\
(n=74)\end{array}$ & $\begin{array}{c}\text { At least } \\
\text { once in } 6 \\
\text { months } \\
(n=43)\end{array}$ & $\begin{array}{c}\text { Never } / \\
\text { almost } \\
\text { never } \\
(\mathbf{n}=\mathbf{2 1}) \S\end{array}$ \\
\hline \multicolumn{5}{|c|}{$\%$ of respondents reading each edition of the following } \\
\hline Wynboer in the WineLand magazine & $74 \%$ & $74 \%$ & $74 \%$ & $71 \%$ \\
\hline Outlook Gazette by Anchor Wine Yeast & $56 \%$ & $42 \%$ & $29 \%$ & $24 \%$ \\
\hline South African Journal of Enology and Viticulture & $46 \%$ & $30 \%$ & $22 \%$ & $30 \%$ \\
\hline \multicolumn{5}{|c|}{$\%$ of respondents reading/consulting the following at least once in 3 months } \\
\hline Textbooks and manuals of winemaking practice & $60 \%$ & $38 \%$ & $40 \%$ & $52 \%$ \\
\hline $\begin{array}{l}\text { Contributions in New World Winemaker } \\
\text { (www.newworldwinemaker.com) }\end{array}$ & $53 \%$ & $41 \%$ & $38 \%$ & $20 \%$ \\
\hline $\begin{array}{l}\text { Trade journals by the wine industries of other } \\
\text { countries }\end{array}$ & $30 \%$ & $32 \%$ & $17 \%$ & $5 \%$ \\
\hline \multicolumn{5}{|c|}{ \% of respondents seeking expert advice from the following at least once in 3 months } \\
\hline Other winemakers in South Africa & $86 \%$ & $88 \%$ & $68 \%$ & $67 \%$ \\
\hline $\begin{array}{l}\text { Staff from wine laboratories responsible for wine } \\
\text { analyses }\end{array}$ & $53 \%$ & $58 \%$ & $41 \%$ & $52 \%$ \\
\hline VinPro consultants & $41 \%$ & $21 \%$ & $24 \%$ & $24 \%$ \\
\hline $\begin{array}{l}\text { Technical consultants from other yeast manufacturing } \\
\text { companies }\end{array}$ & $20 \%$ & $18 \%$ & $10 \%$ & $14 \%$ \\
\hline Technical consultants from Anchor Wine Yeast & $14 \%$ & $5 \%$ & $0 \%$ & $5 \%$ \\
\hline \multicolumn{5}{|c|}{ \% of respondents doing the following at least once in 3 months } \\
\hline $\begin{array}{l}\text { Search the Internet for information on issues related to } \\
\text { winemaking }\end{array}$ & $84 \%$ & $78 \%$ & $69 \%$ & $71 \%$ \\
\hline $\begin{array}{l}\text { Obtain feedback on the quality of wine products from } \\
\text { wine consumers }\end{array}$ & $84 \%$ & $84 \%$ & $59 \%$ & $43 \%$ \\
\hline \multicolumn{5}{|c|}{ \% of respondents attending the following at least twice in the past } \\
\hline $\begin{array}{l}\text { Information sessions/seminars/workshops by } \\
\text { Winetech/VinPro }\end{array}$ & $76 \%$ & $58 \%$ & $55 \%$ & $48 \%$ \\
\hline $\begin{array}{l}\text { Information sessions/seminars/workshops by Anchor } \\
\text { Wine Yeast }\end{array}$ & $64 \%$ & $46 \%$ & $38 \%$ & $14 \%$ \\
\hline $\begin{array}{l}\text { Workshops and short courses by the South African } \\
\text { Society for Enology and Viticulture }\end{array}$ & $63 \%$ & $45 \%$ & $43 \%$ & $19 \%$ \\
\hline $\begin{array}{l}\text { Annual conference of the South African Society for } \\
\text { Enology and Viticulture }\end{array}$ & $40 \%$ & $38 \%$ & $21 \%$ & $10 \%$ \\
\hline
\end{tabular}

\# Frequently consulted winemakers; $\S$ Non-consulted winemakers.

(Winetech/VinPro, 76\% versus 48\%; Anchor Wine Yeast, 64\% versus 14\%; SASEV, 63\% versus $19 \%$ ).

As far as wine consumers being considered an information source, the interviews revealed that they contribute little to a winemaker's operational knowledge and technique, as wine consumers are seldom scientifically grounded. The relevance of consumers as an information source lies in their preferences for particular styles of wine, which helps to align winemaking practice with market demands. According to one of the interviewees:

'The consumer, as far as the consumer goes, in terms of pure winemaking... they are of less relevance because it's mostly conjecture which is basically based on the 
limited knowledge that most consumers have because basically they don't have a lot of wine knowledge. I don't learn anything from them... As far as winemaking style goes, that's a different question. Obviously if you are making a wine you have to stylistically represent it to your clients or consumer base, in which case you listen to your consumers... like someone talks about Chardonnay as being slightly less wooded or they want slightly high residues sugars on red wines or lower alcohols or whatever happens to be, then you are taking notes of that' (Winemaker 1).

Whereas the opinions of wine consumers are generally not informed by scientific research, the same cannot be said of the Internet. By its very nature, an Internet search may or may not render material that is based on scientific research. As one winemaker puts it: "you Google and see what comes up". Also, scientifically informed wine publications (like Wynboer) and science-based service websites (like New World Winemaker) are all accessible online, which supports the argument that some of the information for winemakers on the Internet could very well be based on scientific research evidence.

Lastly, given the prominence of fellow winemakers as both an information source and disseminator of science-based information, the next section briefly explores how winemakers evaluate and integrate the information received from fellow winemakers.

\section{Winemakers' processing of information received from fellow winemakers: three cases}

Relevant insights were provided by three of the six winemakers interviewed, and these are presented here as three individual cases.

Case 1. The first case is a winemaker in his sixties who manages a co-operative cellar and considers himself part of the "old generation". Obviously his accumulated wealth of experience comprises the primary source of information. However, when confronted with a winemaking challenge that experience alone cannot resolve, he normally turns to a fellow winemaker. If the latter is unable to help, more winemaker opinions are sought.

'When you get to a situation where you have hit a hard rock and you don't know left or right, you just phone. That's the first thing that I do. I phone a guy who I think has experience in that area... and if he cannot help, then you go further, you search' (Winemaker 2).

Perception of the relevant experiences of others is the only criterion this winemaker used to select the first candidate to consult. Experience is not so much defined in terms of the number of years of winemaking experience than it is in terms of whether the other person encountered a similar situation. Occasionally the opinions of winemaking consultants and technical consultants at wine yeast manufacturing companies are also sought. In this way a number of opinions are collected and the "most acceptable" is tried out. The latter implies some subjective norm is used for assessing the different opinions, which in this case seems to be the winemaker's own experience and personal knowledge.

'You phone the guys and... let's say, you phone five guys and then you decide which guy's stuff sounds the most acceptable and then you try it; because you don't always 
find the stuff on the Internet or in textbooks or wherever... You listen to what the guys tell you, what the consultant or manufacturers have to say, but then you always go back to what your experience is telling you. Is it really that yeast strain? Will it give you those characteristics?' (Winemaker 2).

It needs to be added that this winemaker's cellar is located in a remote wine region, more than 180 miles from the centre of South African wine research. The winemaker believes that the scientific literature does not cover his region to the same extent than it covers, for instance, the regions closer to Stellenbosch University. Thus, in the absence of relevant codified scientific knowledge in the public domain, the "privately-owned" personal knowledge of oneself and fellow practitioners becomes a more important source.

Case 2. The second case is a winemaker in her twenties from a family of wine farmers and who works at the family's estate cellar. When asked whether she has a preference for any particular information source a description is provided which, at first glance, seems unclear. At closer reading, however, the interconnectivity of three broad categories of sources - self, people and documents — is revealed.

\footnotetext{
'Because I read many articles and everything, it remains at the back of your head, so... actually it starts with talking and then I would say I consult books, and then also winemakers, because it is so much easier if you don't get what you're looking for and you know other winemakers have done it, then you can phone a few winemakers. But it starts with personal knowledge and family-based knowledge obviously and from there you just widen your net... In the end one normally has a combination of things that are all mixed. One winemaker would say, I have just read this article, or will forward it to me, or the trials that the guy did, just quickly take a look at it, and those kinds of things' (Winemaker 3).
}

The "self" as a source of knowledge, which implies personal knowledge, is central for this winemaker as practice "starts with personal knowledge". The winemaker's continuous reading of articles and conversations with family members and fellow winemakers all contribute to a stock of personal knowledge that "remains at the back of your head". This personal knowledge is tapped into during routine practice or when a challenge is experienced, and all new information is evaluated against this ever-expanding stock of personal knowledge.

Case 3. The third case is a winemaker in his thirties who is employed at a large company (a producing wholesaler in the South African context). Obviously the infrastructure and resources of such a large company would affect the winemaker's information acquisition strategy. The company has an in-house research division, which represents a logical starting point for the winemaker whenever information is required.

'Because I work at a [producing wholesaler], we have our own [research division]... guys whose task it is to fiddle and search and who have figured out things through years of experience... I tend to rely on those people's feedback to adjust my decisions to some extent' (Winemaker 4). 
However, where available company resources cannot provide the winemaker with the desired information, winemakers from outside the company are approached. The latter are individuals in the winemaker's social network.

'But say there is something that we don't know anything about, then I would say we will first find out more from other winemakers... mostly friends and colleagues acquired over the years, people who have [studied] with you etcetera, and also people acquainted with them, who you have also met' (Winemaker 4).

Only when both company structures and fellow winemakers cannot provide an answer will the winemaker turn to published materials and documents. This involves resources that are easily available, mostly past study materials and the Internet.

The winemaker's accumulated experiences and personal knowledge also serve as a measure against which to assess incoming claims. Internalised experiences, expressed as a feeling in the "gut", operate as a standard for the winemaker to judge whether an external claim has any merit or not.

'You must be comfortable with the kind of information that you get, you need to trust it. You get rather spooky stuff from the industry. This guy explains to you about that thing, yes, what he has heard or read or whatever, but it needs to coincide with your gut and with your intuition also' (Winemaker 4).

The above quote presents an example of how different knowledge sources have to cohere. It supports a coherence theory of truth, which stipulates that new knowledge claims are tested, not necessarily against reality, but against one's own existing, already accepted set of knowledge claims.

\section{Prominence of the four types of research use among winemakers}

In this section the focus moves from research use as a process - with its concomitant foci on different information sources, their scientific roots, dissemination, and processing - to research use as a typology. As explained in the methodology, research use was operationalized in terms of a four-fold typology: instrumental, conceptual, symbolic and persuasive. Figure 1 shows the winemakers' agreement with the four statements that represent these types of research use. Conceptual use is the most prominent form of research use among winemakers, as $90 \%$ either agreed or strongly agreed that scientific research findings had led them to develop a better understanding of some aspect of their winemaking. In second and third place, ranking closely to each other, are symbolic (80\%) and instrumental (78\%) use respectively. The outcome that is associated with conceptual use, namely increased insight, is internalised and expressed in cognitive form. The same applies to the outcome associated with symbolic use, which is a stronger belief. On the other hand, the outcome associated with instrumental use is purely behavioural as it relates to doing things differently on the basis of scientific research findings.

Moreover, whereas the conceptual, symbolic and instrumental types of research use are directed at the "self", the fourth — persuasive use — is directed at the "other". This 
explains the markedly smaller percentages of respondents $(46 \%)$ who indicated that scientific research had led them to advise other winemakers to also do things differently in their practices.

Lastly, since persuasive use, or the ability to persuade other winemakers to do things differently in their winemaking, implies some form of opinion leadership [10], one would expect a positive relationship between persuasive use and the frequency of a winemaker being approached by others for advice. Responses to the statement about persuasive use were therefore cross-tabulated with responses as to how often winemakers are approached by their peers (Table 5).

Almost two-thirds of winemakers who reported that they are approached by their peers at least once a month also reported persuasive use, compared to only a third of those who are never or almost never approached by fellow winemakers (62\% of 63 respondents versus $33 \%$ of 18 respondents). The fact that respectively $33 \%$ and $27 \%$ of respondents with weak (never/almost never) or relatively weak (at least once in 6 months) linkages also reported persuasive use, could mean one of two things. On the one hand it implies that persuasion could be a natural consequence of social interaction, as winemakers would not typically view social intercourse as an instance of others approaching them for advice. On the other hand it implies that even winemakers at the social periphery could be approached

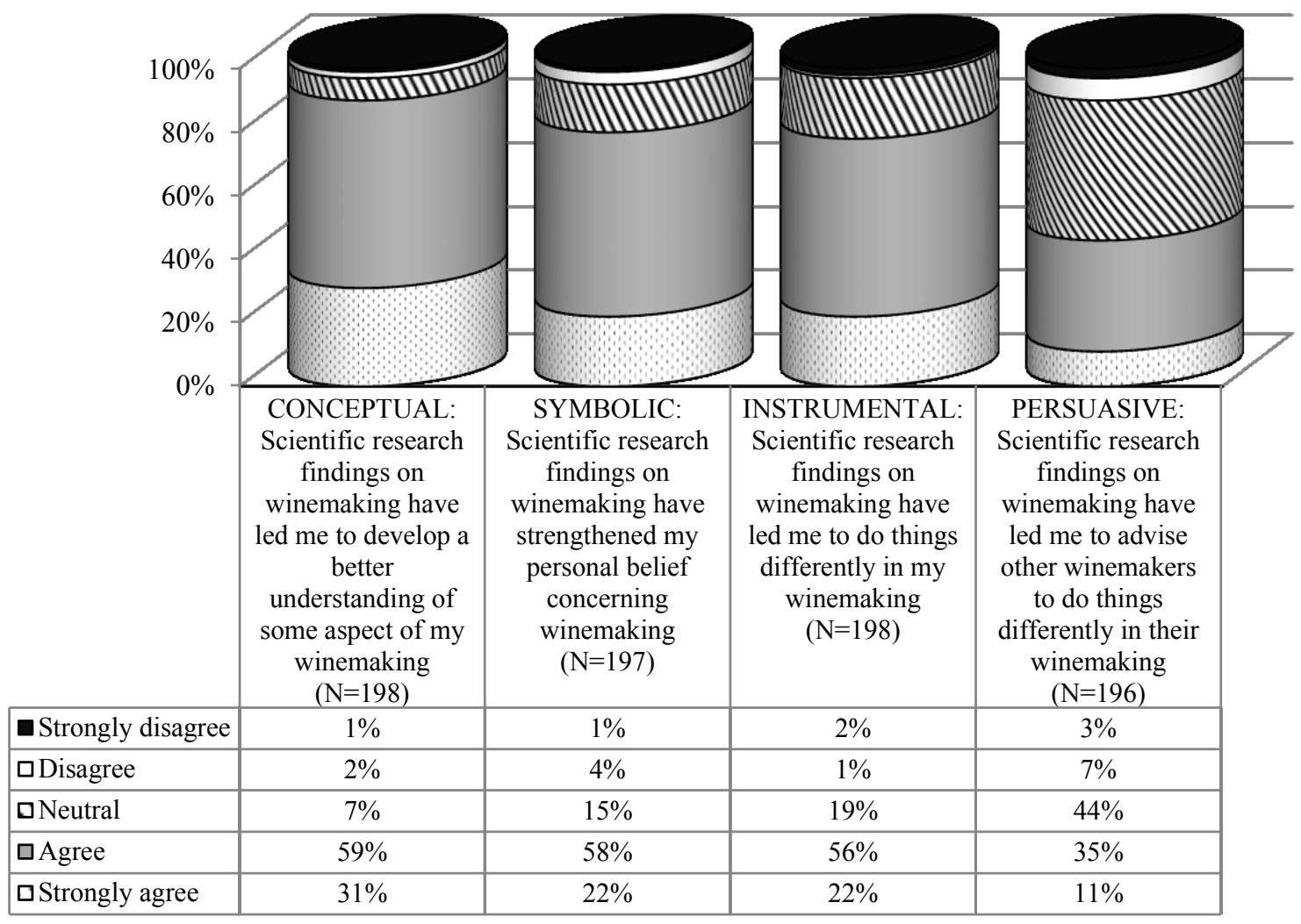

Figure 1. Winemaker Agreement with Statements that Measure Four Types of Research Use. 
Table 5. Relationship between the Statement about Persuasive Use and how often Fellow Winemakers seek Advice/Information from Respondent.

\begin{tabular}{|c|c|c|c|c|c|c|}
\hline \multirow{2}{*}{$\begin{array}{l}\text { Statement } \\
\text { about } \\
\text { persuasive } \\
\text { use }\end{array}$} & \multicolumn{5}{|c|}{$\begin{array}{c}\text { How often fellow winemakers seek advice/information from } \\
\text { respondent }\end{array}$} & \multirow[b]{2}{*}{$\begin{array}{l}\text { Statistical } \\
\text { significance }\end{array}$} \\
\hline & $\begin{array}{c}\text { At least } \\
\text { once a } \\
\text { month } \\
(n=63)\end{array}$ & $\begin{array}{c}\text { At least } \\
\text { once in } 3 \\
\text { months } \\
(n=72)\end{array}$ & $\begin{array}{c}\text { At least } \\
\text { once in } 6 \\
\text { months } \\
(n=41)\end{array}$ & $\begin{array}{c}\text { Never / } \\
\text { almost } \\
\text { never } \\
(n=18)\end{array}$ & $\begin{array}{c}\text { Total } \\
(\mathrm{N}=194)\end{array}$ & \\
\hline $\mathrm{SA} / \mathrm{A}$ & $62 \%$ & $47 \%$ & $27 \%$ & $33 \%$ & $46 \%$ & \multirow{2}{*}{$\begin{array}{c}\text { Chi-square }=13.7 \\
p<0.05\end{array}$} \\
\hline $\mathrm{N} / \mathrm{D} / \mathrm{SD}$ & $38 \%$ & $53 \%$ & $73 \%$ & $67 \%$ & $54 \%$ & \\
\hline
\end{tabular}

Statement about persuasive use: "Scientific research findings on winemaking have led me to advise other winemakers to do things differently in their winemaking."

$\mathrm{SA}=$ Strongly agree; $\mathrm{A}=$ Agree $; \mathrm{N}=$ Neutral $; \mathrm{D}=$ Disagree $; \mathrm{SD}=$ Strongly disagree

Table 6. Relationship between the Four Types of Research Use, expressed as Shared Percentages.

\begin{tabular}{|c|c|c|c|c|}
\hline & $\begin{array}{c}\ldots \text { who also } \\
\text { reported } \\
\text { instrumental } \\
\text { use }\end{array}$ & $\begin{array}{c}\ldots \text { who also } \\
\text { reported } \\
\text { conceptual } \\
\text { use }\end{array}$ & $\begin{array}{c}\text {... who also } \\
\text { reported } \\
\text { symbolic } \\
\text { use }\end{array}$ & $\begin{array}{c}\ldots \text { who also } \\
\text { reported } \\
\text { persuasive } \\
\text { use }\end{array}$ \\
\hline $\begin{array}{l}\% \text { of winemakers reporting } \\
\text { instrumental use }\end{array}$ & -- & $\begin{array}{c}97 \% \\
(\mathrm{~N}=154)\end{array}$ & $\begin{array}{c}88 \% \\
(\mathrm{~N}=154)\end{array}$ & $\begin{array}{c}55 \% \\
(\mathrm{~N}=154)\end{array}$ \\
\hline $\begin{array}{l}\text { \% of winemakers reporting } \\
\text { conceptual use }\end{array}$ & $\begin{array}{c}84 \% \\
(\mathrm{~N}=179)\end{array}$ & -- & $\begin{array}{c}87 \% \\
(\mathrm{~N}=179)\end{array}$ & $\begin{array}{c}49 \% \\
(\mathrm{~N}=179)\end{array}$ \\
\hline $\begin{array}{l}\% \text { of winemakers reporting } \\
\text { symbolic use }\end{array}$ & $\begin{array}{c}86 \% \\
(\mathrm{~N}=158)\end{array}$ & $\begin{array}{c}98 \% \\
(\mathrm{~N}=158)\end{array}$ & -- & $\begin{array}{c}52 \% \\
(\mathrm{~N}=158)\end{array}$ \\
\hline $\begin{array}{l}\text { \% of winemakers reporting } \\
\text { persuasive use }\end{array}$ & $\begin{array}{c}93 \% \\
(\mathrm{~N}=90)\end{array}$ & $\begin{array}{c}97 \% \\
(\mathrm{~N}=90)\end{array}$ & $\begin{array}{c}90 \% \\
(\mathrm{~N}=90)\end{array}$ & -- \\
\hline
\end{tabular}

for advice if it were perceived that they could assist with a challenge because of their knowledge or experience.

\section{Relationship between the four types of research use}

One method to systematically examine the relationship between the four types of research use is to calculate the percentage of winemakers for each category of use who reported each of the remaining three types of use. In other words, the inter-relationship between the types of research use can be expressed as a series of shared percentages. This was done pairwise for all four types of research use, resulting in altogether 12 shared percentages as shown in Table 6.

The three largest percentages $(98 \%, 97 \%$ and 97\%) imply that conceptual use occurs prior to any other form of research use or that none of the other types of use occurs in the absence of conceptual use. This point is best illustrated by interpreting the inverse of the three largest percentages: conceptual use is absent in only $3 \%$ of cases of instrumental use, $2 \%$ of cases of symbolic use and $3 \%$ of cases of persuasive use. Thus, the "better 
understanding" (insight) generated through scientific research is a necessary condition in order for a winemaker (1) to act and start doing things differently, or (2) to interpret the relevant findings as supportive of one's existing belief, or (3) to advise others to do things differently.

As Table 6 further shows, persuasive use cannot really be considered a consequence of any of the other use types, as only between $49-55 \%$ of respondents who reported each of the other three types also reported advising others to do things differently. The "larger" percentage of 55\% nevertheless indicates some tendency among those who made some change themselves on the basis of research findings to also advise others to do so. Another way to interpret Table 5 is to say that persuasive use does not necessarily follow when the other three types of use are reported. However, whenever persuasive use is reported, it almost invariably includes the other three types of use (respectively in 93\%, 97\% and 90\% of cases).

These findings therefore confirm the preliminary insights derived from Table 1, which reconciles the four types of research use by Weiss and Estabrooks with the six stages of research use by Landry, Amara and Lamari $[4,5,7]$. As inferred, conceptual use occurs prior to any of the other three types of research use, and persuasive use mostly occurs at a later stage, once the other three types (conceptual, symbolic and instrumental) are already present.

\section{Conclusions}

Overall the study produced evidence of the widespread use of scientific research in winemaking, as $90 \%$ of South African winemakers, to various degrees, reported a conceptual use of research findings. The latter means that winemakers have a better understanding of certain aspects of their winemaking because of scientific research. The figure of $90 \%$ is exceptional, as there is no single information source (considered a carrier of scientific research) with which such a large percentage of winemakers indicate they frequently engage. The closest is Wynboer in the WineLand magazine, which $74 \%$ of winemakers said they read part or all of each monthly edition.

To account for the figure of $90 \%$ then, it needs to be remembered that knowledge creep, i.e. the process at work in bringing about conceptual research use, implies that there is no single information source or research study responsible for producing the "better understanding". In the words of Weiss:

[P]eople... often do not catalogue research separately in their minds. They interpret it as they read it in light of their other knowledge, and they merge it with all the information and generalizations in their stock. Therefore, they find it difficult, often impossible, to identify the unique contribution that one study, a body of studies, or research in general, has made to their actions (p. 391) [8].

It could further be argued that scientific research reaches the awareness of winemakers without being transmitted through information sources that are traditionally considered 
carriers of science. Fellow winemakers and the Internet are two examples of this, which, given their relative prominence, are probably among the ones most likely to shape the average winemaker's approach and expanding his or her stock of winemaking knowledge. The "diffuse, undirected seepage" of knowledge that Weiss [6] refers to as knowledge creep, and which subconsciously influences a practitioner's actions, most likely also occurs in relation to these two frequently consulted information sources. By implication then, information conveyed by the Internet and fellow winemakers could also include traces of scientific research.

Thus, advice communicated by fellow winemakers very often has an underlying scientific base, but knowledge of its scientific roots over time "fades away" because of knowledge creep. Regular exposure to different sources of scientific information, together with the practical application of relevant information, can result in practitioners accumulating a wealth of workable knowledge that becomes detached from its various origins when recalled for transmission at a later stage. There also appears to be a close association between a winemaker's stock of personal knowledge/experience and the assessment of information received from fellow winemakers. Indications are that the information received from fellow winemakers, whether scientific or not, is first tested against the recipient winemaker's internalised knowledge and experience, before being tried out in practice.

Moreover, the fact that fellow winemakers are seen as a frequent source and disseminator of information is in no way unique in the broader context of practitioners. Medical practitioners also heavily rely on their medical colleagues for information and advice [1216]. Asking colleagues is often the quickest way for busy practitioners to acquire relevant information, and also provides a sense of reassurance or direction in instances of uncertainty, apart from allowing a practitioner immediate access to the context-specific knowledge of others.

Lastly, wine information events appear to be the key information sources of winemakers who are most frequently consulted by others, i.e. winemakers who act as nodes in social networks and communities of practice. This is not surprising as wine information events represent occasions where the latest scientific results for the South African wine industry are disseminated and discussed. Attendance of such organised events can provide winemakers with a leading edge in terms of the best of current evidence of scientific research on winemaking products and processes. It therefore makes sense that regular attendance of wine information events would be a defining characteristic of central winemakers who act as nodes in social networks, setting them apart from those at the periphery. It could further be argued that nodal winemakers themselves have tried out the research findings and therefore understand the practical issues and consequences emanating from that research. As a result, nodal winemakers are more inclined to use scientific research in the form of persuading others to follow their example of doing things differently in their winemaking practice. 


\section{References}

[1] B. Rotter (2009), Art and science in winemaking, retrieved 3 Aug 2013, available at: http://www.brsquared.org/wine/Articles/ArtSci.htm.

[2] R.F. Rich (1997), "Measuring knowledge utilization: Processes and outcomes", Knowledge and Policy: The International Journal of Knowledge Transfer and Utilization 10(3): 11-24.

[3] J. Knott and A. Wildavsky (1980), "If dissemination is the solution, what is the problem?", Knowledge: Creation, Diffusion, Utilization 1(4): 537-578.

[4] R. Landry, N. Amara and M. Lamari (2001), "Climbing the ladder of research utilization: Evidence from social science research", Sci. Commun. 22(4): 396-422.

[5] C.H. Weiss (1979), “The many meanings of research utilization”, Public. Admin. Rev. 39: 426-431.

[6] C.H. Weiss (1978), "Broadening the concept of research utilization", Sociol. Sym. 21: 20-33.

[7] C.A. Estabrooks (1999), "The conceptual structure of research utilization", Res. Nurs. Health 22(3): 203-216.

[8] C.H. Weiss (1980), "Knowledge creep and decision accretion”, Knowledge: Creation, Diffusion, Utilization 1(3): 381-404.

[9] WineLand (2010), South African wine industry directory 2010/11, WineLand Publications, Paarl, South Africa.

[10] SAWIS (2011), South African wine industry statistics: Annual statistics for 2010 by the SA Wine Industry Information and Systems, retrieved 3 Aug 2013, available at: http://www.sawis.co.za.

[11] E.M. Rogers (2003), Diffusion of Innovations, 5th ed., The Free Press, New York, U.S.A.

[12] E.J.C. Boerkamp, F.M. Haaijer-Ruskamp, J.C. Reuyl et al. (1996), “The use of drug information sources by physicians: Development of a data-generating methodology", Soc. Sci. Medi. 42(3): 379-388.

[13] D.G. Covell, G.C. Uman and P.R. Manning (1985), "Information needs in office practice: Are they being met?", Ann. Intern. Med. 103(4): 596-599.

[14] J.W. Ely, J.A. Osheroff, M.H. Ebell et al. (1999), "Analysis of questions asked by family doctors regarding patient care", Brit. Med. J. 319(7206): 358-361.

[15] M. Falshaw, Y.H. Carter and R.W. Gray (2000), "Evidence should be accessible as well as relevant", Brit. Med. J. 321: 567.

[16] R. Smith (1996), "What clinical information do doctors need?", Brit. Med. J. 313(7064): 1062-1068.

\section{Author}

Nelius Boshoff $(\mathrm{PhD})$ is a Senior Lecturer at the Centre for Research on Evaluation, Science and Technology (CREST), Stellenbosch University, South Africa. His professional interests include studies of knowledge uptake and research collaboration as well as bibliometrics with a focus on Africa. Email: scb@sun.ac.za.

How to CITE: N. Boshoff, Use of scientific research by South African winemakers, JCOM 13(01)(2014)A01. 